The International Struggle for

New Human Rights 
PENNSYLVANIA STUDIES IN HUMAN RIGHTS

Bert B. Lockwood Jr., Series Editor

A complete list of books in the series is available from the publisher. 


\title{
The International Struggle for New Human Rights
}

\author{
EDITED BY CLIFFORD BOB
}

\section{$\overline{\text { PENN }}$}

University of Pennsylvania Press

Philadelphia 
Copyright @ 2009 University of Pennsylvania Press

All rights reserved. Except for brief quotations used for purposes of review or scholarly citation, none of this book may be reproduced in any form by any means without written permission from the publisher.

\section{Published by}

University of Pennsylvania Press

Philadelphia, Pennsylvania 19104-4112

Printed in the United States of America on acid-free paper

$\begin{array}{llllllllll}10 & 9 & 8 & 7 & 6 & 5 & 4 & 3 & 2 & 1\end{array}$

Library of Congress Cataloging-in-Publication Data

The international struggle for new human rights / edited by Clifford Bob. p. cm. - (Pennsylvania studies in human rights)

Includes bibliographical references and index.

ISBN 978-0-8122-4131-0 (alk. paper : acid-free paper)

1. Human rights-Case Studies. I. Bob, Clifford, 1958JC571.I6362 2009 